\title{
RADICAL TPACHPR
}

A SOCIALIST, FEMINIST, AND ANTI-RACIST JOURNAL ON THE THEORY AND PRACTICE OF TEACHING

Inventing Our University: Student-Faculty Collaboration in Critical University Studies

by Heather Steffen

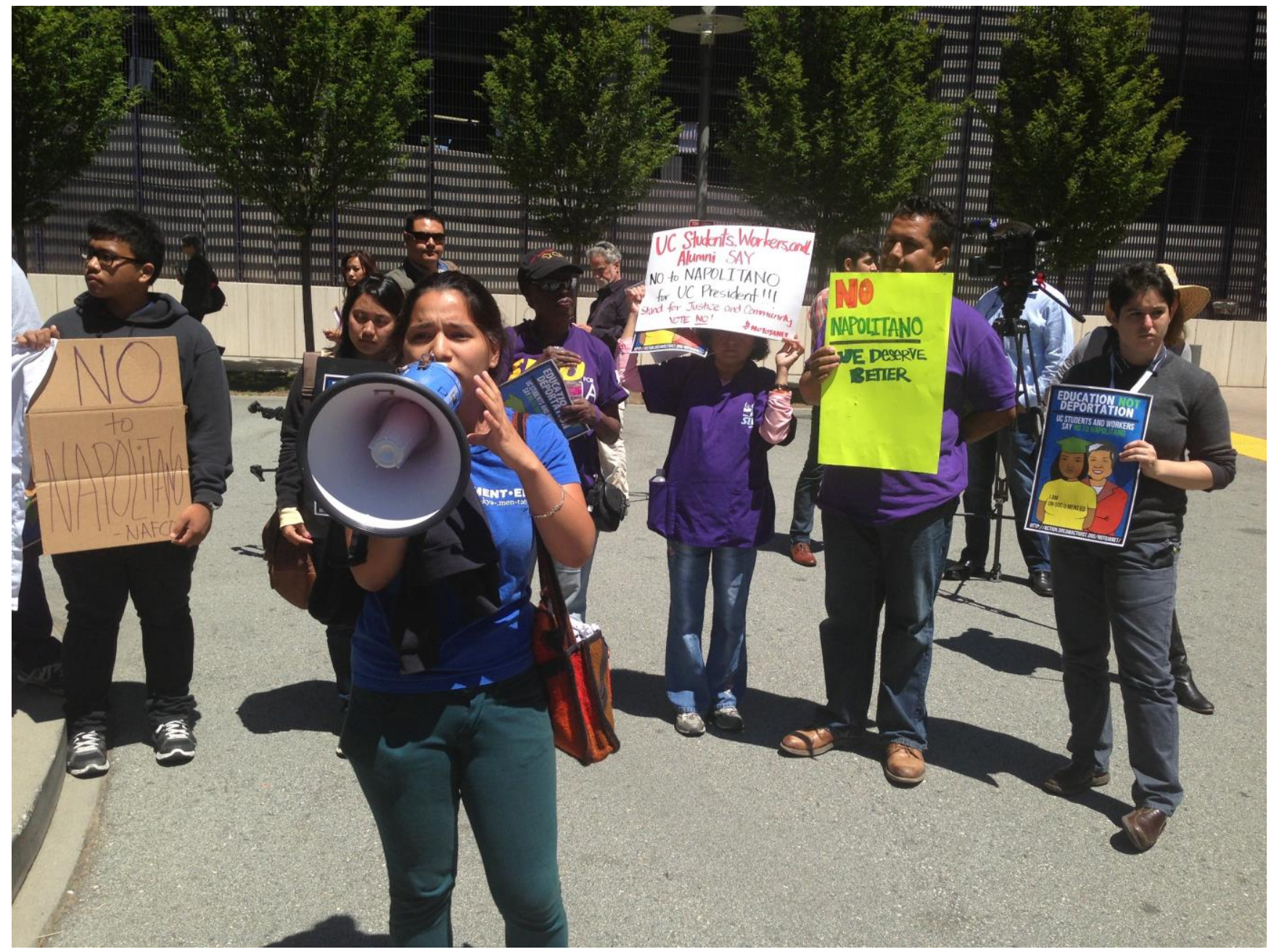

GLORIA CAMPOS FROM UC SANTA BARBARA, PHOTO BY STEVE RHODES, 2013 
C omposition scholar David Bartholomae famously argues that "Every time a student sits down to write for us, he has to invent the university for the occasion...he has to invent the university by assembling and mimicking its language while finding some compromise between idiosyncrasy, a personal history, on the one hand, and the requirements of convention, the history of a discipline, on the other. He must learn to speak our language. Or he must dare to speak it or to carry off the bluff" (61). Bartholomae's point is that learning academic writing is a trickier business than we imagine. It forces students to claim a starting point, a place of authority from which to begin "writing their way into a new community" before they have attained (or realized they possess) authority over the subject (Bartholomae 78). "Inventing the university" means re-inventing the university's discourse over and over until the student can "appropriate (or be appropriated by)" the language of scholarly argument (Bartholomae 64). What strikes me about Bartholomae's opening lines is the implication that somewhere out there lies "the university" and that the student's job is to locate it and enter through the gateway of academic discourse.

In what follows, I tug at the threads of Bartholomae's statements to explore the ways that student-faculty collaboration in critical university studies might reveal spaces of agency, knowledge, and solidarity that open up when we pause together at moments of assemblage, mimickry, and compromise. At the moments, I mean, before the university's invention is a fait accompli, when we encounter the university as an unfinished institution and when we might "dare to speak" what we want from it, to call its bluffs, to mock rather than mimic its "requirements of convention." I hope to show that partnering with undergraduate students in critical university studies research offers an opportunity to multiply these moments of possibility.

\section{My interest in collaborative} research grows out of my participation as a researcher and mentor on All Worked Up: A Project about Student Labor. My partners on the project are two University of California, Santa Barbara, seniors, Chelsea Brandwein and Erika Carlos, and a recent alumna, Nastacia Schmoll. Together, we are conducting a series of interviews with UCSB student workers, asking them about their jobs, career plans, educational experiences, finances, and how working affects their academic, social, and family lives. Our analysis of the interviews is qualitative and situated within critical university studies, student affairs, pedagogical studies, and public debates about higher education. As a project fusing research, writing, and social justice goals, we present our analyses in multiple modes: we are creating a website at www.allworkedup.org, writing in academic and public genres, attending conferences, facilitating workshops and community discussions, and collecting footage for a documentary film. All Worked Up will be a multi-year project, and we are just one year in.

In this essay, I draw on my recent participation in the All Worked Up Project, my experience teaching critical university studies (CUS) and as a CUS researcher, and the scholarly literature on undergraduate research to consider what students get from and contribute to CUS. What does critical university studies offer to students? What can students bring to critical university studies? And how might such exchanges lead us beyond scholarship, enable us to build solidarity, and empower us to invent a new university, our university, that serves students, scholarteachers, and its diverse publics rather than the imperatives of neoliberal capital?

\section{Research as Learning}

Undergraduate research is the object of a lively, if small, wing of education scholarship. Students have assisted faculty since the beginnings of the research university, but educators' and administrators' interest in undergraduate research as a pedagogical tool really intensified with the publication of the Boyer Commission's Reinventing Undergraduate Education in 1998. The Boyer Report issued an imperative to reform undergraduate education to emphasize research- and inquiry-based learning. Institutions of every type responded by establishing offices of undergraduate research, hiring coordinators, and funding grants. A number of models exist for undergraduate research: independent studies, directed readings courses, research assistantships, senior theses or capstone projects, and collaborations between students and faculty. No matter the model, undergraduate research projects typically serve one or more of three purposes: to foster student learning, to contribute to the advancement of knowledge, or to assist faculty (Beckman and Hensel 43). (They may also serve activist and social justice purposes, which I discuss below.) Educators debate whether undergraduate research should be product- or process-oriented, whether the science model works in the humanities, and whether topic choice should come from students or faculty, but the pedagogical consensus is that research experiences are immensely beneficial for student learning and development.

The scholarly literature on undergraduate research demonstrates that student research promotes cognitive, social, and emotional learning, and it provides a site for the development and practice of writing, communication, and argumentation skills. It sparks interest in advanced education, improves retention of minority and at-risk students, and makes resumes stand out. ${ }^{1}$ Student research supports genuine, sustained, one-on-one contact between faculty and students, and it erects teamwork and negotiation challenges with real stakes. It is a form of problem-posing education. When universities and professional organizations provide venues for students to share their research, they can hone presentation and 
design skills and experience what it means to speak as an expert. When mentors guide students through a thesis or coauthor with them, college writers have a chance to practice the whole academic writing process, not just its rushed end-of-term analogue. They get to read and compose in the invisible but ubiquitous genres of application and review-conference abstracts, panel and workshop proposals, pitches, submission guidelines, readers' reports, grant applications, and business emails. They learn to tackle feedback and persist through rewrites, resubmissions, and rejection. As John Orr relates, his student collaborator was struck by the duration of the revision process: "a part of her learning process was seeing the need for exhaustive revision, something that she-a very skilled undergraduate writer-was not particularly experienced in doing" (4). Student investigators begin to know "the frustrations and exhilaration we all feel as researchers" (Grobman and Kinkead xxii). Undergraduate research experiences move students from being "undergraduate writers" to writers who can speak with authority, clarity, and precision-and who know how much work that takes.

While developing investigative and communication skills, student researchers are exposed to new ways of conceptualizing knowledge, learning, creativity, and innovation as processes. They experience intense, sustained attention to an object of study or problem, getting to see what happens if you let your curiosity play out. As collaborators or principal investigators, they face the messiness of knowledge production, including the menial labor, clerical acumen, and administrative effort it requires. They have to find time in busy schedules to get research and writing done, even if it feels at times like a burdensome hobby, and they have to decide when to privilege their research over other commitments and when to let it slide. Student researchers encounter the uncertainties of inquiry, "learn to handle ambiguity," and find out that "failure is a possible outcome," though not necessarily a negative one (Beckman and Hensel 43; Schantz 29).

Perhaps most importantly, student researchers confront the incompleteness of knowledge. Today's undergraduates grew up in the era of No Child Left Behind (NCLB), the Common Core, and Race to the Top. They should not be faulted if their concept of knowledge reflects the assessment movement's epistemology of "predictability; quantification and comparison; standardization, transparency, and a reductive notion of democratic publics" or its emphasis on acquiring "discrete skills and pieces of information in place of genuine intellectual engagement" (Emery 259). Research experiences can undo some of this damage because they offer students what Kim Emery calls "the true key to the academic kingdom: the secret that our future is unknown, that research will reveal surprises, that difference offers a safeguard against narrow-mindedness, that incoherence is a condition of possibility, and that knowledge is neither finite nor fixed" (259). When we give students the chance to become producers of knowledge rather than consumers, we counter the neoliberal socialization of NCLB, college applications, and lecture courses. We give students the chance to redefine themselves as meaning-making agents.

\section{Questioning the University}

Research in critical university studies may be a particularly effective site for developing student agency, because undergraduates often know more about their universities than their faculty, at times seeming to occupy an alternate institution, existing unnoticed alongside ours. (Compare for a moment the way your students use the library and what you do there.) They come to critical university studies as experts in their own right, so the task of building students' confidence is already underway, as is their development of questions and curiosity. When I assign research projects in critical university studies courses, students investigate topics from sexual assault to compensation for athletes to affirmative action, the causes of high tuition, and support for undocumented students. Their interests understandably skew toward student life issues, but they never have trouble coming up with research questions. I am constantly reminded of how different are their immediate concerns from those of most CUS scholars. Students ask us to view the university through different lenses.

\section{Research in critical university studies may be a particularly effective site for developing student agency, because undergraduates often know more about their universities than their faculty, at times seeming to occupy an alternate institution, existing unnoticed alongside ours.}

In turn, critical university studies defamiliarizes the institution and transforms students' everyday lives into objects of study. In a 2007 Radical Teacher article, Jonathan Vincent and Danny Mayer describe teaching a unit about 1960 s campus activism in their writing classes and bringing students to their universities' archives to develop projects about the protests and conflicts in which their predecessors took part. Vincent and Mayer explain that "teaching our students the histories of campus-based political radicalism and taking them to on-campus sites of struggle allowed us to work against the increasingly corporatized agendas actively recoding campuses as 'ideologically neutral' bastions of allegiance to social order and capitalist production." As their students pored over photos of crowds, police lines, and draft card burnings, they came to a broader vision of "what a university campus is and can be" (Vincent and Mayer 19). Similarly, when students begin to wonder what kinds of lives their TAs, lecturers, and groundskeepers are living or when they ask why it's so hard to get a seat in a 1,200-person lecture course, they take a step toward viewing the university as an institution built up by a series of choices made by people in particular historical, political, economic, and cultural contexts. 
As I've witnessed again and again in my CUS writing classes, the immense potential of this first, questioning step often dissipates into hurried final papers and wishes for a lovely break. A one-term course does not afford time for extended analyses and the development of informed strategies to reclaim the university. But in collaborative research projects, we can find the intellectual space, resources, and dedicated time to move from questioning to analysis, critique, and collective action.

\section{Critical University Studies as Analytical Framework}

In research projects and collaborations, students get to spend a significant amount of time sitting with a problem, reading the literature on it, and possibly even producing their own data. They have time for real analysis of the problem, not just a surface-level overview of its main contours. Student researchers in critical university studies can come to understand how their own experiences are situated in the broad sweep of historical, political, economic, and cultural trends. Learning the long history of the U.S. university is critical for such projects, because the historical functions of higher education and the political and economic forces that have shaped its mission shape our expectations for today's universities. ${ }^{2}$ Faculty mentors and collaborators should also be attentive to students' understanding of recent shifts that impact higher education. The historical juncture in which students find themselves is defined by the post-Fordist mode of production and by the hegemony of neoliberal thinking in politics and policy making. These two facts constrain our students' lives, but most are unable to name or explain them.

\section{Learning the long history of the U.S. university is critical for such projects, because the historical functions of higher education and the political and economic forces that have shaped its mission shape our expectations for today's universities.}

The All Worked Up Project's interviewees, for instance, are keenly aware that they will graduate into an economy that has not bounced back from the 2008 crisis, and they recognize the historical specificity of student debt and campus diversity. But they are hard-pressed to connect their experiences with economic or political shifts that took place before 2008. As listeners and researchers, however, Chelsea, Erika, and Nastacia, are contextualizing interviewees' comments within the university's current situation. Part of the AWU project is asking how universities participate in the creation of flexible workers ready to accept insecurity and trade unpaid labor for a shot at paid employment. As our interviewees describe "side hustles" driving for Uber or working under the table to avoid losing financial aid, it is becoming clear to the AWU team that "higher education is an instrument of its social structure, reinforcing class discrimination rather than alleviating it" (Williams).

Chelsea, Erika, and Nastacia are practicing the approach of CUS scholars. They are testing out what Jeffrey J. Williams has called the "oppositional stance" of critical university studies and exploring what insights emerge when one "turns a cold eye on higher education . . . and foregrounds its politics, particularly how it is a site of struggle between private commercial interests and more public ones." College students have a lot of chances to learn how to read texts and rhetorical acts, but it is much more challenging to teach them how to find points of articulation between a close reading and its relevant contexts. By prompting institutional analysis, critical university studies research can bridge this gap.

Undergraduate research also offers many opportunities to understand the bureaucratic workings and hierarchies of the university that surround all our pedagogical, scholarly, and extracurricular activities. Even a simple grant application can open up questions about how institutions work. When the AWU team decided to apply for a UCSB Undergraduate Research and Creative Activities (URCA) Grant, for instance, Chelsea and Erika discovered that their official faculty mentor had to be "senate faculty," and I wasn't on the list of potential mentors. Asking what that meant opened a space to talk about the different faculty ranks and why a contingent, non-senate lecturer and postdoctoral researcher like me might not be allowed to mentor students through a long-term funded research project. As Chelsea drafted the URCA grant application and, later, a proposal for the Conference on College Composition and Communication (CCCC) Undergraduate Research Poster Session, we addressed the two genres' different rhetorical situations-audiences, purposes, and contexts-and the reasons UCSB and CCCC have chosen particular modes of supporting undergraduate research. In moments like these, the AWU team is encountering the ways ideas can be shaped and structured by the demands of institutions. We are thinking together about the complicated funding and decision-making structures that always enmesh teaching and knowledge production. As part of a collaborative CUS research project, even mundane academic tasks can become opportunities to learn that "the university is [both] a discursive and material phenomenon" and how those two realms interact (Williams).

In the extended analytical space of a collaborative research project, students have the freedom to practice mixed methods research. Because critical university studies is a "cross-disciplinary" field, its work tends to "draw on research from any relevant area to approach the problem" at hand (Williams). Student researchers can explore the power of investigations that mix interpretive, quantitative, ethnographic, and archival research strategies. The core of AWU's research on student labor is our interviews, but we are also collecting data about our participants' financial situations, weekly schedules, academic achievements, and extracurricular activities that could later be used for quantitative analysis. As we move further into the project, we are performing interpretive analyses on the interviews 
themselves, lining up our findings with the literature on student affairs and studies from multiple disciplines, and planning community discussions to capture faculty perspectives. Though AWU has not yet taken us to the archives, Vincent and Mayer's teaching about sixties student activism demonstrates the powerful inspirations and lessons that might be found there as well.

\section{Critique Is a Transferable Skill}

The ability to critique the work of institutions is a particularly important skill for students to gain in our present political climate. The political traction of populist distrust of government, experts, and universities makes it crucial that students be equipped to understand how institutions may serve democratic purposes while simultaneously contributing to structural racism and inequality. Learning to critique an institution means learning to distinguish its positive social functions from its damaging ones and to develop a position that avoids unwarranted generalizations like those found in mainstream political discourse.

In our work on All Worked Up, one small example of an opportunity to develop the nuances of a critique has emerged around the issue of training student workers for emotionally and physically risky campus jobs. Resident advisors (RAs) at UCSB receive intensive training in how to handle situations like excessive drinking, reports of sexual assault, and other emergencies, and they enjoy strong support from supervisors who emphasize self-care strategies, like the motto that RAs are people first, students second, and RAs third. RAs tend to feel wellequipped to deal with difficult scenarios and know how to get help when they need it.

On the other hand, when we interviewed a former Community Service Officer (CSO), one of his chief complaints about the job was lack of training. CSOs are students who work for the UC Police, acting as liaisons between police and the undergraduate community, patrolling the campus at night, following suspicious individuals, and sometimes serving as first responders to dangerous or violent events. When UCSB's neighboring student community, Isla Vista, was the site of a mass shooting, CSOs in the area were asked to aid the police in keeping order and steering students away, even before the shooter was apprehended. Our interviewee noted that he was trained for dealing with fires and mental health emergencies, but the training was limited and did not cover many situations he encountered. Despite risks and bad conditions that led him to quit, he has little hope for improvement because there are always more students applying to work as CSOs than there are jobs. Training for student workers in high-risk positions has become one of the AWU team's key areas for further investigation, and Chelsea in particular is working toward a critique of campus training protocols that asks how RA training could be used as a model for improved CSO preparation.

Building a critique of an institution and its functions forces you to define your criteria of evaluation, to envision and describe what you believe should be the university's mission and its social roles. Undergraduate research in critical university studies provokes students' civic imagination and invites them to "develop the habit of asking 'what if' and 'why not'" (Beckman and Hensel 43). The All Worked Up Project aims to offer students (and eventually faculty as well) a forum to conceptualize a better university. We ask our interviewees how they define the "college experience," what they believe is the purpose of higher education, what they would change about it, and how faculty could better understand the lives of working students.

Today's students think a lot about what higher education can and should be, and they are hungry for chances to articulate and refine their ideas. This was brought home to me during a discussion about "Democratizing Education, Race and Privatization" held during a January 18 teach-in, the Day of Democratic Education, organized by the UC Santa Barbara Faculty Association. Diane Fujino opened the doors of her class on Asian-American social movements to students and faculty from across the university, and panelists spoke about NCLB, juvenile crime policies, and civil rights era Freedom Schools. During the $\mathrm{Q}$ and $\mathrm{A}$, a professor in the audience suggested that we all take a few minutes to talk with a partner about our visions for higher education. Then students were invited to share their thoughts. So many hands went up that we didn't get to hear from everyone who wanted to speak, and the students who were called on had clear ideas. For example, they emphasized a desire for ethnic studies courses to take a central place in the general education curriculum and replace western-centric requirements, and they forcefully advocated for our campus to take steps to become a truly inclusive, diverse space, pointing out ways that its reality does not match its rhetoric.

\section{The policies that are wrecking higher education-austerity budgeting, the casualization of teaching, and the exploitation of students as sources of revenue and labor, among others-have all been established by coalitions of administrators, politicians, foundations, and corporate interests who are deeply connected by shared economic interests, ideological orientations, and resource pools.}

\section{Enacting Solidarity through Citizen Professionalism}

In fields with both intellectual and social justice goals, like critical university studies, radical scholar-teachers must continually look for ways to connect our research and writing to collective action. Research collaborations involving students, faculty, staff, and community members are not only important sites for learning and teaching, but 
also for creating the personal relationships, networks, knowledge base, and skills required to build solidarity and enact change in the U.S. higher education system. In the struggle to reclaim the university, we are up against incredibly powerful antagonists. The policies that are wrecking higher education-austerity budgeting, the casualization of teaching, and the exploitation of students as sources of revenue and labor, among others-have all been established by coalitions of administrators, politicians, foundations, and corporate interests who are deeply connected by shared economic interests, ideological orientations, and resource pools. As Marc Bousquet has put it, "management enjoys solidarity." To have any chance at re-inventing our universities, students, faculty, and community members must develop our own strong bonds of solidarity, pool our resources, and share our skills and knowledge.

If critical university studies scholars and their allies want to "teach for social justice," Eric Gutstein explains, "it is important to express solidarity with one's students and their communities, in both words and deeds" ("Building" 201). Meaningful political relationships with students, according to Gutstein,

Involve taking active political stands in solidarity with students and their communities about issues that matter. Political relationships also entail teachers sharing political analyses with students as much as possible. Finally, they include talking with students about social movements, involving students themselves in studying injustice, and providing opportunities for them to join in struggles to change the unjust conditions. (Reading 133)

When scholar-teachers invite students into the "inner sanctum" of our research and writing, and when we partner with them in their struggles, we lay the relational foundations of trust, commitment, and mutual support that enable collective action (Orr 3 ).

In her research on "Faculty and Staff Partnering with Student Activists," Adrianna Kezar explores how faculty enact solidarity with student activists. She spoke with faculty from colleges spanning the institutional spectrum to discover what motivates them to partner with activists, how deeply they get involved, and how different campus contexts shape such partnerships. Kezar's key finding is that faculty contributions to student causes do not have to be flashy or highly visible to be incredibly effective. Most faculty, Kezar discovered, prefer to partner with students in "invisible" or "moderately visible" ways that serve educational goals as well as activist purposes (471). Pursuing change in higher education through collaborative CUS research projects may attract new faculty allies, especially those without tenure, who feel more comfortable mentoring or working with undergraduate researchers than cosigning an editorial or holding a protest sign.

In fact, according to Kezar, moderately visible partnerships like collaborative research may be even more useful than turning up at a protest. In "common and everyday experiences" like these, Kezar contends, "students have the most opportunity for student development because the experiences occur regularly, provide ongoing opportunities to practice activism, and teach students the everyday skills of being a good citizen" (476). Through behind-the-scenes connections, faculty and students can work to benefit each other. Faculty can mentor student activists in developing strategies, negotiating with administrators, and mapping campus power dynamics (Kezar 471). For their part, students can undertake certain direct actions, like occupations, boycotts, walkouts, or media appearances, that could pose significant employment risks for the contingent faculty majority (Kezar 470). By partnering with student activists in research projects, we can build not only the critical and analytical skills discussed above, but also shared bases of practical and strategic knowledge about our institutions.

In this brief discussion of the educational and political potential of student-faculty collaboration in critical university studies, I have so far left aside the important issue of power differentials between students, faculty, and other community members. I don't have space here for the serious consideration this topic deserves, but I would like to suggest that a promising point of departure for conversations about power, knowledge, and public service in critical university studies is Harry Boyte's concept of "citizen professionalism" (citizen in its broad, not legal, sense). A veteran of the civil rights movement, Boyte is now a scholar of public work and civic education, and an abiding concern of his research and teaching is to answer the question, "What is the role of the credentialed expert in struggles for social justice and equality?" The history of university critique gives ample evidence that academic professionals' commitments to public service and democratic engagement can easily morph into discourses of elitism and technocracy if scholar-teachers are not sufficiently reflective.

Boyte proposes a version of politically-engaged professionalism that can serve as a model for how critical university studies scholar-teachers should interact with student researchers and our university communities. Citizen professionals, he writes, "decide to work with citizens"; "are proud of their knowledge and the craft of their discipline, but also know their limits"; and "recognize that solving complex problems requires many sources and kinds of knowledge" (Boyte 144). Rather than assuming that training and credentialing automatically afford accurate, objective, or privileged knowledge, Boyte's citizen professionals seek to integrate technical and professional knowledge with the community's values. They "learn respect for the insights of those without formal credentials," "develop a sense of everyday politics as the negotiation of the gritty plurality of the human condition," and "recognize their own uncertainties" (Boyte 145). As teachers, scholars, and collaborators, I believe proponents of critical university studies should strive to live up to this definition and to model an engaged, committed, and professional approach to learning, researching, and writing for both our students and our publics. If we are to rescue what is best in the university and to preserve its ability to fulfill its public mission, faculty can no longer work alone. We must meet our students where they are, help them imagine what is possible, and work with them in solidarity 
and partnership to invent an institution that will be genuinely our university.

\section{Coda: The All Worked Up Story}

Our work on the All Worked Up Project is possible only because our team has the right combination of people, skills, commitment, and institutional support, and those have come through a combination of initiative and luck. In this coda I share how these factors work together for readers interested in taking on student-faculty collaborative research projects.

As a scholar of academic labor and the history of the U.S. university, I have wanted to investigate student labor for a while now, because it's something of a black box in both traditional higher education studies and critical university studies. In CUS, researchers have only scratched the surface of student labor and related issues. Marc Bousquet's How the University Works features a chapter about student workers at UPS' Louisville hub, Jeffrey J. Williams has written extensively on the ways debt affects all aspects of student life, and I have looked at the hidden curriculum of student internships. ${ }^{3}$ Chelsea planted the seed of the AWU Project with a striking autoethnographic essay on resident assistants' labor that she wrote for my fall 2015 Writing for the Humanities class. When the UC Santa Barbara Writing Program later that year announced the creation of the Raab Writing Fellowships to support undergraduate research and writing, I thought of Chelsea right away because I knew she was keen to expand her study if she could get the resources and find the time. We talked a week later, and I asked what kind of product or text she would like to work toward. Chelsea said without hesitation, "A documentary." "Let me think about it," I hedged, wondering how to find a midpoint between a feature-length film and yet another research paper.

Around that time, I also talked to Erika about the project and the challenges Chelsea and I were anticipating as newcomers to multimedia writing and design. The next morning I had an email from Erika asking if she might join the team. Knowing Erika's talent and skill in multimedia from her work as the Writing Program's tech and design assistant, I was thrilled. The three of us got together, Chelsea and Erika hit it off, and we started mapping out research questions, methods, and a work plan. By the time they had drafted the fellowship application, the documentary film was back on the table, but now it was just one part of a sprawling multimodal, mixed-methods research project that would also include interviews with dozens of students, a website, presentations, and writing for popular and academic audiences.
As their faculty mentor and not having collaborated to this extent with undergraduate students before, I was a little daunted by the prospect of the next year's work. I was more daunted when we received the Raab Committee's responses-everyone was enthusiastic about the project, but the word "ambitious" appeared enough times to set my academic codeword alarms buzzing. My fears were put to rest, though, when Chelsea, Erika, and I discussed the responses. For Chelsea, Erika, and Nastacia, "ambitious" is not just a description of All Worked Up; it is a gauntlet thrown down, a welcome challenge to do more and do it better. "Ambitious" has become the fight song of the AWU team.

We began recruiting and interviewing student workers in early fall 2016. The interviews are long, about two hours each, and the conversations are sprawling. Before each interview we collect the participant's work history, academic profile, demographic data, and extracurricular commitments on an information sheet; and we choose several primary questions. Even with this preparation, we have discovered that it is almost impossible to keep the interviews on any linear or narrow track. Once students begin to talk about their work or their choice of major, they get into the backstories of their families and finances, explanations of why they work, or the reasons they're majoring in accounting rather than music (or why they're majoring in music anyway). It was during one such interview that we discovered Nastacia's difficult story and her extraordinary ability to reflect on its meaning and context, and we invited her to join the team. The interviews are videotaped, and we share them amongst our team on a secure university-provided cloud storage site.

The logistics of group research, especially when it explores an understudied area, are complicated and time consuming. Our team has been meeting for two hours a week every week this academic year and for a portion of the summer before. Each meeting has an agenda we set ahead of time, because two hours a week is a lot but it's also not really enough time together. We use the meetings for planning, goal setting, document and draft reviews, and all the minutiae of applications, travel plans, and reimbursements, most of which are new tasks for Chelsea, Erika, and Nastacia. Between meetings each team member completes several "assignments," which may be interviewing, website coding, video editing, participant recruitment, or drafting abstracts, proposals, or articles. In this way, we have managed to get a very complicated application for the use of human subjects approved by UC Santa Barbara's Institutional Review Board, submitted two successful conference proposals, been awarded multiple grants, completed twenty two-hour interviews, published ten edited videos on www.allworkedup.com, composed a research poster and workshop for faculty, and drafted a blog post and three articles.

Without the combination of independent work, constant group discussion, and collaborative writing workshops, none of us could be this productive for a 
project that is an add-on to our usual work. Both Chelsea and Erika are full-time students who work at least twenty hours per week. They considered taking independent studies with me to reserve time for All Worked Up, but as we looked into that option, we realized it boiled down to paying the university for research work we could do without their taking out more loans. Nastacia has four parttime jobs while she searches for full-time employment. And I am appointed as a lecturer in Writing and postdoctoral scholar in English, teaching writing and English courses, working on a book manuscript, and participating in a collaborative multi-year project for my postdoctoral research.

Most undergraduate research projects will not appear on students' transcripts without raising their tuition, and most faculty will be compensated or earn time off from regular teaching duties for mentoring or collaborating with students. Thus, in our team's opinion-and it's something we talk about a lot-scheduling tasks at a reasonable and regular pace, dividing up the interesting work and the grunt work equally, relying on each other for feedback and inspiration, and meeting weekly will likely be key to any successful, long-term student-faculty collaborative research project. To sustain energy and engagement, team members should use each other as resources, be honest about their abilities and available time, and approach writing and other creative activities with humility, enthusiasm, and the knowledge that they will turn out better with group workshopping and revision.

For the ambition toward student-faculty collaboration to come to something, institutional supports-both material and cultural-are also crucial. Our project and its outcomes thus far have been enabled by a patchwork of small grants and fellowships from different programs at UC Santa Barbara. The Writing Program's Raab Fellowships offered Chelsea and Erika $\$ 1,000$ each to use in any way that would benefit the project. With these funds, we were able to purchase microphones, memory cards, and other technical equipment required to make high-quality interview videos. They also applied for and were awarded a UCSB Undergraduate Research and Creative Activities (URCA) grant of $\$ 400$, with which we printed a poster, bought web hosting space, and purchased Adobe Creative Cloud licenses. Supplemental URCA Travel Mini-Grants of $\$ 250$ helped to pay for Chelsea and Erika to travel to Portland, OR, to present a poster on "Writing the Lives of Working College Students" at the Conference on College Composition and Communication. As a Raab Writing Fellows faculty mentor, I earned $\$ 500$ in travel funds, and I applied for a UCSB Non-Senate Faculty Professional Development Grant to cover my travel to Portland. We used most of my Raab funds to defray Nastacia's CCCC travel costs as well. Currently we are preparing to facilitate a praxis session on "Enacting Solidarity with Student Workers and Students in Debt" at the May 2017 Cultural Studies Association conference in Washington, DC. Chelsea and Erika have applied for CSA's Student Travel Grants, and I will apply for funding through the Writing Program to attend.

This is a long list of small grants, but we have discovered that there is great enthusiasm at our institution to support student research, even though the project's collaborative nature is throwing up some roadblocks. We feel strongly that at research universities and other colleges, faculty and students should not be shy about going after funding, even arguing for the creation of new funding streams to support undergraduate inquiry. They can make all the difference in being able to achieve ambitious goals by offering both financial opportunities and recognition of the work's value. As we enter the next phases of the project-ramping up our interviewing pace, analysis, writing, and planning to begin work on the documentary in January 2018-we are encountering the challenge of seeking large external grants. Again, institutional resources are proving to be available and invaluable, as we have begun discussions with a foundation relations specialist in our development office. Though it can seem strange to reach out, humanities faculty and contingent scholar-teachers should begin making more use of such experts and resources on our campuses, especially as available public funding comes under political threat.

Most important to undertaking a project like All Worked Up might be finding oneself on a campus whose institutional culture honors not only research but studentfaculty collaboration and research about students' lives. In the UCSB Writing Program-which is staffed almost entirely by NTT lecturers who teach full-time-we have found all these factors, as well as colleagues who demonstrate interest in our work, support Chelsea and Erika to write about student labor in their courses, and respect my research about students as just as valuable as research on any other topic. Further, the job security I enjoy, even if it comes in two-year contracts, was a determining factor in my decision to take the risk of devoting so much time to an "extra" project.

Moving forward, the AWU team hopes to publish and present our findings in a number of venues and modes. Chelsea, Erika, and Nastacia have plenty of experience writing argumentative essays for coursework, and they are all planning careers they know will incorporate a lot of writing. They want to practice genres they know (personal narratives, blog posts, and creative nonfiction), but they also want to stretch and try out new modes of communicating in academic articles, research posters, long-form multimodal and online essays, biographies, interviews, and, of course, documentary film. Chelsea, Erika, and Nastacia are all working on article drafts right now, writing in genres from news stories to memoirs to advice columns, and they just published a coauthored essay, "Conference Call: Putting Academic Research into Practice," on UCSB's Undergraduate Research blog.

The topics and questions coming up in the interviews have both confirmed our hypotheses and brought to light issues that Chelsea, Erika, and Nastacia have not encountered as students and that I have not found in the literature. We hope to add new dimensions to the existing scholarly and public conversations around student debt, the difficulties faced by new graduates on the job market, time management, self-care for student activists, and the gig and sharing economies. New questions we want to raise for community members and critical university studies scholars primarily revolve around the centrality of 
experiences of inequality in the lives of students. Our interviews are revealing a stark and somewhat unsurprising divide between students with financial support from their parents and those who depend on grants, scholarships, loans, and their income to pay for tuition and living expenses.

What has surprised us, however, are the different ways this inequality impacts students: For instance, many of our Chicanx and Latinx interviewees are supporting their families while attending school, either financially or with caregiving labor. The traditional responsibility to take care of one's spouse and children later in life weighs heavily on some students, most of whom are cis straight men, and they worry that this responsibility will be more difficult for them to meet than it was for their parents' generation. Several of our women interviewees have narrated experiences of sexual assault and harassment with calm, strength, and wisdom, but when we ask about their debt, they break down and cannot finish sentences. The picture of today's undergraduate workers emerging from the All Worked Up Project at times confirms CUS scholars' worst fears about student life in the neoliberal university, but it also reminds us that students are capable of incredible resilience, tenacity, creativity, and power. The job facing the AWU team now is to communicate this picture in all its complexity.

\section{Notes}

1. On the learning and development benefits of undergraduate research, see Mary Beckman and Nancy Hensel, "Making Explicit the Implicit: Defining Undergraduate Research"; Lisa A. Burke and Monica K. Cummins, "Using Undergraduate Student-Faculty Collaborative Research Projects to Personalize Teaching"; Joyce Kinkead, "Learning Through Inquiry: An Overview of Undergraduate Research"; Biren A. Nagda, et al., "Undergraduate Research Partnerships Affect Student Retention"; and Reed Wilson, "Researching 'Undergraduate Research' in the Humanities."

2. See Jeffrey J. Williams, "History as a Challenge to the Idea of the University."

3. See Williams, "Debt Education" and "The Pedagogy of Debt"; and Steffen, "Student Internships and the Privilege to Work."

\section{Works Cited}

Bartholomae, David. "Inventing the University." Writing on the Margins: Essays on Composition and Teaching. Bedford/St. Martin's P, 2005, pp. 60-85.

Beckman, Mary, and Nancy Hensel. "Making Explicit the Implicit: Defining Undergraduate Research." Council on Undergraduate Research Quarterly, vol. 29, issue 4, 2009, pp. 40-44.

Bousquet, Marc. How the University Works: Higher Education and the Low-Wage Nation. NYU Press, 2008.

Boyte, Harry. "Citizen Professionals." The Citizen Solution: How You Can Make a Difference. Minnesota Historical Society, 2008, pp.
143-157.

Brandwein, Chelsea, Erika Carlos, and Nastacia Schmoll. "Conference Call: Putting Academic Research into Practice." UCSB Undergraduate Research Blog, 11 April 2017, https://undergrad. research.ucsb.edu/blog/. Accessed 11 April 2017.

Burke, Lisa A., and Monica K. Cummins. "Using Undergraduate Student-Faculty Collaborative Research Projects to Personalize Teaching." College Teaching, vol. 50, issue 4, 2002, pp. 129133.

Emery, Kim. "Outcomes Assessment and Standardization: A Queer Critique." Profession, 2008, pp. 255-259.

Grobman, Laurie, and Joyce Kinkead. "Introduction: Illuminating Undergraduate Research in English." Undergraduate Research in English Studies, edited by Laurie Grobman and Joyce Kinkead, National Council of Teachers of English, 2010, pp. ixxxxii.

Gutstein, Eric. "Building Political Relationships with Students." Opening the Research Text: Critical Insights and In(ter)ventions into Mathematics Education, edited by Elizabeth de Freitas and Kathleen Nolan, Springer, 2008, pp. 190-204.

Reading and Writing the World with Mathematics: Toward a Pedagogy for Social Justice. Routledge, 2006.

Kezar, Adrianna. "Faculty and Staff Partnering with Student Activists: Unexplored Terrains of Interaction and Development." Journal of College Student Development, vol. 51, issue 5, 2010, pp. 451-480.

Kinkead, Joyce. "Learning Through Inquiry: An Overview of Undergraduate Research. New Directions for Teaching and Learning, vol. 93, 2003, pp. 5-17.

Nagda, Biren A., Sandra R. Gregerman, John Jonides, William von Hippel, and Jennifer S. Lerner. "Undergraduate Research Partnerships Affect Student Retention." The Review of Higher Education, vol. 22, issue 1, 1998, pp. 55-72.

Orr, John. "Not Only for the Sciences: Undergraduate Research in the Humanities." Perspectives on Undergraduate Research and Mentoring, vol. 2, issue 1, 2013, pp. 1-5.

Schantz, Mark S. "Undergraduate Research in the Humanities: Challenges and Prospects." Council on Undergraduate Research Quarterly, vol. 29, issue 2, 2008, pp. 26-29.

Steffen, Heather. "Student Internships and the Privilege to Work." Works and Days 59/60, vol. 30, issues 1 and 2, 2012, (also Cultural Logic, 2010), pp. 379-393.

Vincent, Jonathan, and Danny Mayer. "Teaching Radicalism from the University Archives." Radical Teacher, vol. 79, 2007, pp. 19-26.

Williams, Jeffrey J. "History as a Challenge to the Idea of the University." jac, vol. 25, issue 1, 2005, pp. 55-74.

"Debt Education: Bad for the Young, Bad for America." Dissent, 2006, http://www.dissentmagazine.org/ article/?article=657. Accessed 4 April 2017.

"Deconstructing Academe: The Birth of Critical University Studies." Chronicle of Higher Education, 19 Feb. 2012, www.chronicle.com/article/An-Emerging-FieldDeconstructs/130791/. Accessed 23 Feb. 2012.

"The Pedagogy of Debt." College Literature, vol. 33, issue 4 2006, pp. 155-169.

Wilson, Reed. "Researching 'Undergraduate Research' in the Humanities." Modern Language Studies, vol. 33, no. 1/2, , pp. 74-79. (c) EY-NO-NO

This work is licensed under a Creative Commons Attribution-Noncommercial-No Derivative Works 3.0 United States License.
This journal is published by the University Library System of the University of Pittsburgh as part of its D-Scribe Digital Publishing Program, and is cosponsored by the University of Pittsburgh Press.

RADICAL TEACHER 